\title{
The effect of reserpine, oestradiol and in-vitro perfusion on oviduct calcium levels in the mouse during egg transport
}

\author{
Bernadette Lee and K. E. Kendle \\ School of Pharmacy, Robert Gordon's Institute of Technology, Schoolhill, \\ Aberdeen AB9 1FR, U.K.
}

\begin{abstract}
Summary. Mouse oviduct calcium content, determined by atomic absorbance after ashing of the tissue, showed a significant fall on Day 2 of pregnancy followed by a significant rise on Day 3. This pattern was altered by administration of reserpine and oestradiol in doses which were shown to alter the rate of egg transport. In-vitro perfusion of the oviduct, capable of maintaining muscular activity and back and forth movement of eggs for $24 \mathrm{~h}$, was associated with lack of forward progressive motion of eggs and by a more rapid increase in tissue calcium levels during incubation than occurred in vivo.
\end{abstract}

\section{Introduction}

The transport of ova through the oviduct is thought to be effected primarily by the contractile activity of the oviduct musculature (Blandau, Boling, Halbert \& Verdugo, 1975). Since smooth muscle activity depends upon calcium ions (Lullman, 1970), changes in contractile activity in the oviduct during egg transport may be mediated through changes in tissue calcium content or distribution. In the present study oviduct calcium content in mice during normal, delayed and accelerated egg transport in vivo and during perfusion in vitro has been determined. Reserpine (Bennett \& Kendle, 1967) and oestradiol (Humphrey, 1968) were used to produce retardation and acceleration of egg transport respectively.

\section{Materials and Methods}

Albino mice of the RGIT/SLAC strain were housed under constant conditions of $12 \mathrm{~h}$ light (08:00-20:00 h) and $21 \pm 1^{\circ} \mathrm{C}$. Water and Oxoid Pasturised Breeding diet for rats and mice were always available. Mature virgin females, $6-12$ weeks old, were paired with mature males and examined each morning for the presence of a vaginal plug which was taken as evidence of successful copulation (Day 1 of pregnancy), and copulation was assumed to occur at 24:00 h on the previous day. The mice were killed at the times indicated in 'Results'.

Egg transport in vivo. The position of the eggs in the oviduct and the mean percentage oviduct traversed by the eggs were determined by the methods of Bennett \& Kendle (1967) and Kendle \& Bennett (1969).

Oviduct calcium levels. Oviducts removed at autopsy were blotted on filter paper, cleaned of fat, and then ashed in pairs in silica crucibles at $450^{\circ} \mathrm{C}$. The ash was dissolved in $1 \mathrm{ml} 6 \mathrm{M}$ hydrochloric acid (Analar: B.D.H. Chemicals Ltd, Poole), evaporated to dryness, redissolved and evaporated, and then dissolved in $4 \mathrm{ml} 0.3 \mathrm{M}$-hydrochloric acid. The final volume was adjusted to $10 \mathrm{ml}$ with distilled water and calcium concentrations were measured by atomic absorption spectroscopy. The results were converted to $\mu \mathrm{g} / \mathrm{mg}$ wet weight of tissue. 
The detection limit of the assay was $0.05 \mu \mathrm{g} / \mathrm{ml}$ with linearity up to $1.5 \mu \mathrm{g} / \mathrm{ml}$ and the interand intra-assay variations were $<15 \%$ and $<1 \%$, respectively. Blank readings automatically zeroed. All samples, standards and the blanks contained $0.1 \%(\mathrm{w} / \mathrm{v})$ calcium-free lanthanum chloride (Koch-Light Laboratories Ltd, Bucks) to prevent anionic interference.

Oviduct perfusion in vitro. The oviducts were removed from animals killed on Day 2 of pregnancy ( 34 h post coitum) and straightened. Each oviduct was placed in an air-tight, optically transparent chamber (Text-fig. 1). The chamber was perfused with a Ringer solution of the following composition (mM): $\mathrm{NaCl}, 153 \cdot 8 ; \mathrm{KCl}, 5 \cdot 6 ; \mathrm{CaCl}_{2}, 2 \cdot 16 ; \mathrm{NaHCO}_{3}, 5 \cdot 81$; glucose, 5; which was gassed with pure oxygen and maintained at $33^{\circ} \mathrm{C}$. Microscopic examination of the oviducts in the chambers enabled location of the eggs, calculation of the mean percentage oviduct traversed by the eggs, and assessment of oviduct contractions, counted per minute, and motility, based on a 5 -point scale $(0=$ no movement, $1=$ very weak, $2=$ moderate, $3=$ strong, $4=$ very strong).

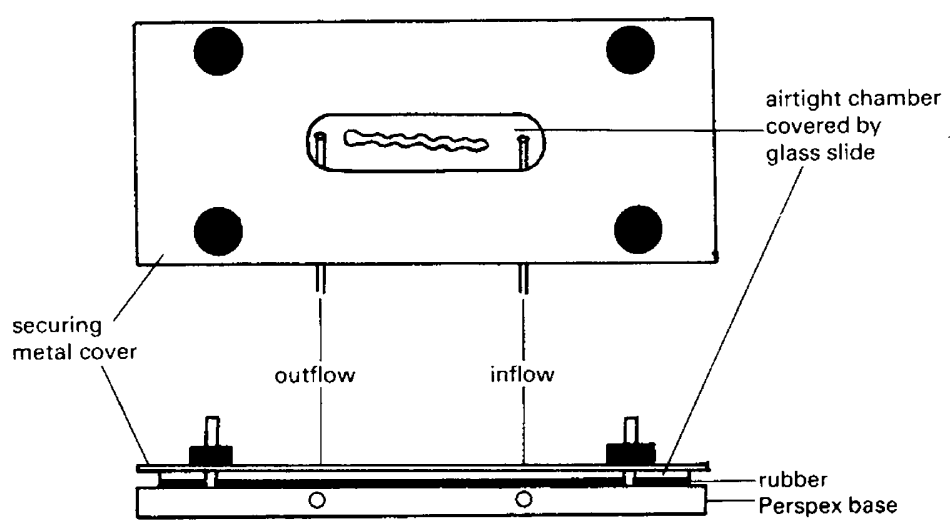

Text-fig. 1. Perfusion chamber for in-vitro oviduct preparation.

Untreated mice were killed at 10:00 h on Days 1, 2, 3, 4 or 5 for determination of egg positions and oviduct calcium levels. The effects of oestradiol and reserpine on egg transport and oviduct calcium levels were then investigated and compared with vehicle-treated controls.

The reserpine (Courtin and Warner, Lewes) stock solution consisted of $300 \mathrm{mg}$ reserpine $+375 \mathrm{mg}$ citric acid in $6 \mathrm{ml}$ benzyl alcohol $+15 \mathrm{ml}$ Tween 80 , made up to $100 \mathrm{ml}$ with distilled water (see Bennett \& Kendle, 1967). Dilutions were made with distilled water. Mice were treated intraperitoneally with $2 \mathrm{mg}$ reserpine/ $\mathrm{kg}$ or with vehicle $(10 \mathrm{ml} / \mathrm{kg})$ at $09: 00 \mathrm{~h}$ on Day 1 of pregnancy (i.e. $9 \mathrm{~h}$ post coitum) and killed at 10:00 h on Days 1, 2, 3, 4 or 5 for determination of egg positions and oviduct calcium values.

Oestradiol (B.D.H.) was prepared as a stock solution $(8 \mathrm{mg}$ in $10 \mathrm{ml}$ absolute alcohol (B.D.H.)) and dilutions were made with $0.9 \%(\mathrm{w} / \mathrm{v}) \mathrm{NaCl}$. Mice were given an intraperitoneal injection of $2 \mu \mathrm{g}$ oestradiol at $33 \mathrm{~h}$ post coitum (Day 2, 09:00 h). Control animals were treated with saline $(10 \mathrm{ml} / \mathrm{kg})$. Oestradiol-treated animals were killed at 36,40 and $60 \mathrm{~h}$ and controls at $12,33,36,40,60$ and $84 \mathrm{~h}$ post coitum. The oviducts were removed for determination of egg transport and calcium content.

\section{Results}

Egg transport and calcium levels in vivo

The results are shown in Tables 1 and 2. Reserpine retarded the rate of egg transport by approximately $24 \mathrm{~h}$ (Table 1), all the eggs not entering the uterus until Day 5. Oestradiol accelerated egg transport (Table 2). Calcium levels in the untreated mice were lowest on Day 2 of pregnancy (Table 1) with a significant rise on Day 3. As precision within calcium assays was 


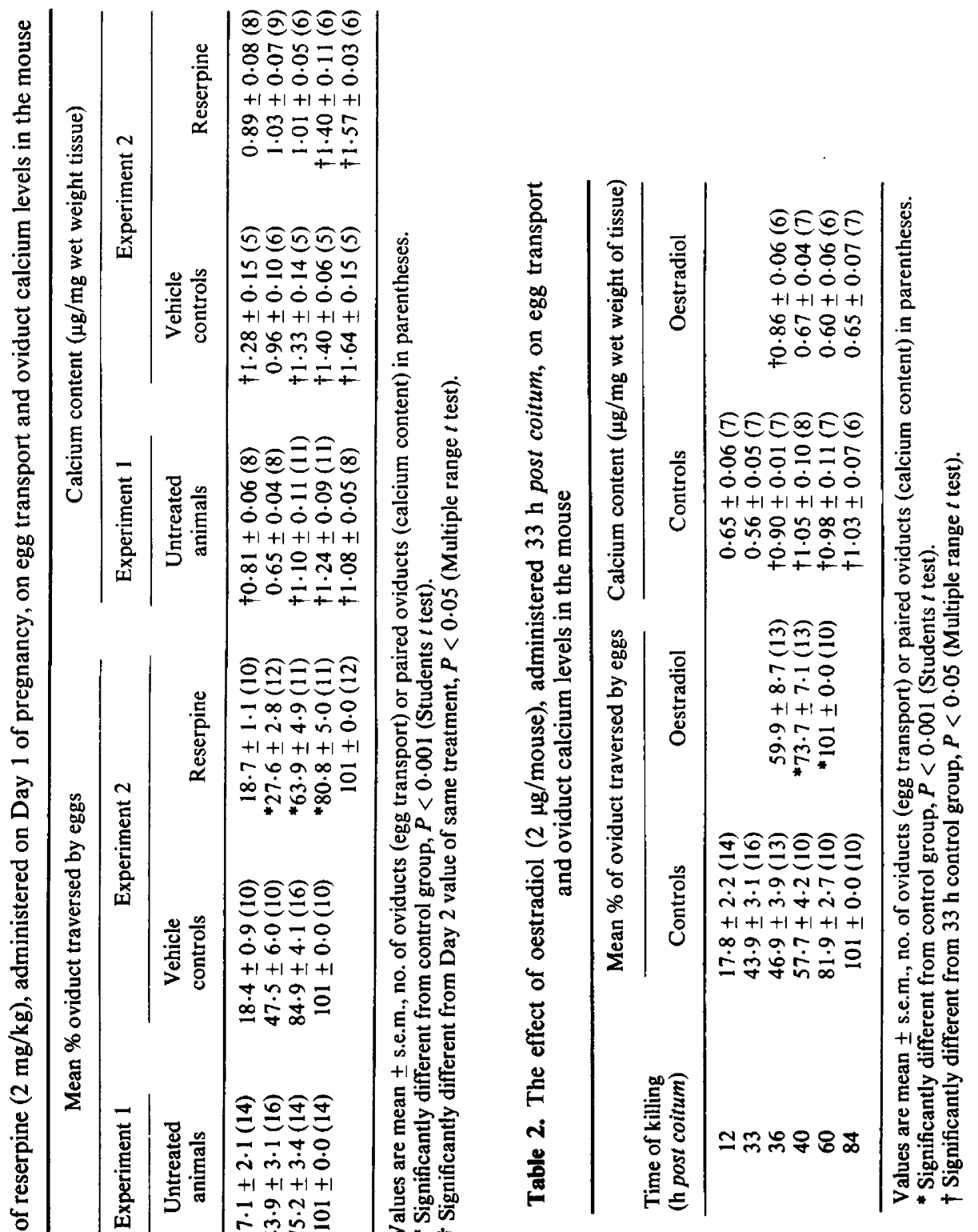


much greater than between assays, only within-experiment comparisons could be made. The calcium level on Day 2 was arbitrarily selected as the reference level to which the other values were compared using the multiple range $t$ test. The same pattern was observed after reserpine vehicle but there were no changes in calcium levels after reserpine treatment until the increase observed on Day 4 (Table 1). In the saline-treated controls calcium levels rose significantly between $33 \mathrm{~h}$ and $36 \mathrm{~h}$ post coitum and the rise was sustained at 40,60 and $84 \mathrm{~h}$ while in the oestradiol-treated mice at 40,60 and $84 \mathrm{~h}$ levels had fallen and were not significantly different from the $33 \mathrm{~h}$ control (Table 2).

\section{Calcium levels during in-vitro perfusion}

The oviduct musculature remained viable for at least $20 \mathrm{~h}$, showing rhythmic contractions although the frequency decreased significantly $(P<0.001$, paired $t$ test $)$ from $12.9 \pm 0.98$ to $7.5 \pm 1.21$ contractions/min $(n=13)$. The eggs moved backwards and forwards within the oviduct lumen but made no forward progression along the isthmus (mean \% oviduct traversed at $1 \mathrm{~h}$ and $20 \mathrm{~h}$ was $46 \cdot 1 \pm 5 \cdot 25$ and $45 \cdot 7 \pm 5 \cdot 69$ respectively, $n=13$ ).

Table 3. Effect of incubation in vitro on oviduct calcium levels in the mouse

\begin{tabular}{lccc}
\hline & \multicolumn{3}{c}{ Time (h post coitum) } \\
\cline { 2 - 4 } & 34 & \multicolumn{3}{c}{40} & 58 \\
\hline In vivo & $0.41 \pm 0.01(6)$ & $0.46 \pm 0.03(6)$ & $0.52 \pm 0.03(6)^{*}$ \\
In vitro & & $0.58 \pm 0.05(6)^{*}$ & $0.49 \pm 0.03(6)^{*}$ \\
\hline
\end{tabular}

\footnotetext{
Values are mean \pm s.e.m., no. of paired oviducts in parentheses.

* Significantly different from the $34 \mathrm{~h}$ control group, $P<0.05$ (Multiple range $t$ test).
}

The calcium levels of 6 oviducts were measured at 6 and $24 \mathrm{~h}$ after the start of perfusion (40 and $58 \mathrm{~h}$ post coitum respectively) and comparisons were made with the values obtained for the oviducts from 6 untreated animals killed at 34,40 and $58 \mathrm{~h}$ post coitum. The results are shown in Table 3. Calcium levels rose in vivo after copulation but were lower than the values represented for similar tissue in Table 2. The values obtained in vitro were comparable to those found in vivo but rose earlier.

\section{Discussion}

Normal egg transport rates were observed in untreated mice and in mice given saline or reserpine vehicle. The mean percentages of the oviducts traversed by the contained eggs on Days 1, 2, 3 and 4 of pregnancy showed close correlation between experiments and with previous investigations (Kendle \& Bennett, 1969). Although the absolute concentrations of calcium showed considerable variation between experiments a consistent pattern was observed during normal egg transport. Levels fell between Days 1 and 2 then rose sharply between Days 2 and 3 and were subsequently maintained at the higher level. Thus Day 2 of pregnancy, when egg movement is most rapid as the eggs are transported from the isthmo-ampullary to the utero-tubal junction, was consistently the time at which calcium levels were lowest.

Pharmacological alteration of the rate of egg transport was associated with alteration of the pattern of calcium levels. Reserpine, which delayed egg transport, abolished the Day 2 fall and delayed the significant rise by $24 \mathrm{~h}$, while oestradiol accelerated egg transport and prolonged the low Day 2 levels.

The in-vitro mouse oviduct preparation allowed observation of oviduct muscle motility and although forward and backward movement of the contained eggs occurred the eggs did not 
progress. The more rapid rise of calcium levels in vitro than in vivo might be inhibiting egg transport via calcium-induced changes in the pattern of oviduct contractility, as the calcium content of smooth muscle is known to be dependent on extracellular calcium levels (Schatzman, 1961). The apparently later rise in calcium levels in vivo in this experiment compared with the data in Table 2 is probably due to variation in the actual time of mating between experiments as this was assumed to be constant for convenience in describing the data but would in fact be subject to variation of undetermined magnitude both within and between experiments.

The hypothesis that the concentration of calcium ions could play an important role in the regulation of oviduct contractility and egg transport is supported by the findings in this study of a definite pattern of concentration changes during normal egg transport and of a close correlation between the effects of pharmacological stimuli on the rate of egg transport and on oviduct calcium concentrations. Correlation has been shown between the ability of segments of the oviduct to transport ova (Pauerstein, Anderson, Chatkoff \& Hodgson, 1974) and to exchange calcium (Hodgson \& Daly, 1975) in the rabbit, indicating the importance of calcium distribution in oviduct function. Further study is therefore needed to clarify the relationship between calcium content and distribution in the tissue.

\section{References}

Bennett, J.P. \& Kendle, K.E. (1967) The effect of reserpine upon the rate of egg transport in the fallopian tube of the mouse. J. Reprod. Fert. 13, 345348.

Blandau, R.J., Boling, J.L., Halbert, S. \& Verdugo, P. (1975) Methods for studying oviductal physiology. Gynaecol. Invest. 6, 123-145.

Hodgson, B.J., \& Daly, S. (1975) The role of calcium in concentration of the oviduct. In Ovum Transport and Fertility Regulation, pp. 182-196. Eds M. J. K. Harper, C. J. Pauerstein, C. E. Adams, E. M. Coutinho, H. B. Croxatto \& D. M. Paton. Scriptor, Copenhagen.

Humphrey, K.W. (1968) Effects of oestradiol $3: 17 \beta$ on tubal transport in the laboratory mouse. $J$. Endocr. 42, 17-26.
Kendle, K.E. \& Bennett, J.P. (1969) Studies upon the mechanism of reserpine induced arrest in egg transport in the mouse oviduct. J. Reprod. Fert. 20, 429-434.

Lullman, H. (1970) Calcium fluxes and calcium distribution in smooth muscle. In Smooth Muscle, pp. 151-165. Ed. E. Bulbring. Arnold, London.

Pauerstein, C.J., Anderson, V., Chatkoff, M.L. \& Hodgson, B.J. (1974) Effects of oestrogen and progesterone on the time-course of tubal ovum transport in rabbits. Am. J. Obstet. Gynec. 120, 299308.

Schatzmann, H.J. (1961) Calciumaufnahme und Abgabe am Darmmuskel des Meerschweinchen. Pflügers Arch. ges. Physiol. 274, 295-310. 